Proceedings of the Second Annual Forestry Symposium 1996: Management and Sustainable Utilization of Forest Resources, Sri Lanka, 6-7 December 1996. (Eds. Amarasekera, HS, Ranasinghe, D M S HK and Finlayson, $W$. Published by Department of Forestry and Environmental Science, University of Sri Jayewardenepura, Sri Lanka (1998)

\title{
SOCIAL FORESTRY AS AN ALTERNATIVE STRATEGY FOR FOREST PLANTATION DEVELOPMENT
}

\author{
Thosapala Hewage \\ Director, Forestry Sector Development Division \\ Ministry of Agriculture, Lands and Forestry
}

\begin{abstract}
The alarming trend of deforestation and forest degradation has created the need to adopt alternative strategies for sustainable forest plantation development. It is wiciely accepted that plantations undertaken by the Forest Depariment (FD) alone are inadequate to create the tree cover necessary to meet all the wood related needs of the country. Studies made for the Forestry Sector Master Plan (FSM MP) showed that about 70\% of the wood supply is derived from non-forest sources anci that this trend can be expected to continue for the next 25 years. In these circumstances, ways and means have to be found of increasing the part played by the rural people in tree growing, in order to improve the productivirty of the non-forest wood resources. In keeping with the government's economic policy, ways must be developed and promoted for involving farmers, the estate sector, communities and other private groups in forest plantation establishment and management. The National Forestry Policy (NFP) of 1995 already includes provisions to give emphasis to the promotion of social forestry. In order to give effect to these policies several far-reaching strategies have been proposed under the FSMP, such as allowing home gardens and other agroforestry systems to be established on leased state land that has been degraded or deforested, introducing incentives to encourage the maintenance of home gardens, and conversely to discourage the conversion of home gardens to other land uses. Various types of institutional support, including credit, technical assistance and research will be provided as required for the development of social forestry by state agencies that will work with the rural people.
\end{abstract}

\section{Present status}

It is well known that the area of natural forests in this country has declined drastically during the last 100 years. The alarming trend of both deforestation and forest degradation has caused grave environmental problems, as well as regional shortages of fuelwood and timber. In order to mitigate these effects it has become necessary to devise alternative strategies for sustainable forest plantation development. The main alternative sources for the present and future wood supplies of the country are trees grown on non-forest land and forest plantations. It has been realized that planting by 
the Forest Department (FD) alone cannot create the tree cover necessary to meet all of these needs, because of the ever increasing demand for industrial forest products, logs and fuelwood that is created by the expanding population and economy.

Meanwhile, the limited availability of land for forestry, specially for new plantations, is seen as a major constraint on the FD's efforts to expand the country's forest cover. Land is a very scare resource and it will get ever scarcer in the future. The FD has estimated that except for about 38,000 ha of land available in the dry zone, new plantation establishment in other areas of the country may have to be confined to the regeneration of existing plantations and enrichment planting of degraded natural forests.

Furthermore, site conditions are very variable, and finding suitable sites in large blocks is difficult. There are no proven, reliable, profitable establishment methods for many of these sites. If plantations are established on a large scale. without paying attention to socio-cconomic conditions and local needs, the people oppose them. Then it is found that socio-economic issues come to the fore, partly in the guise also of environmental concerns.

The annual planting rates by the FD have been declining compared to the $1960 \mathrm{~s}$ and $1970 \mathrm{~s}$, and the forest plantation sub-sector has become increasingly dependent on foreign funding. The FD has had no real incentive to improve the cfficiency of plantation management and increase the marketable output, since it cannot benefit from improving its efficiency or even from selling the produce. Marketing and harvesting are carried out by the State Timber Corporation (STC). As the STC is not the forest owner or manager, it has no responsibility for forest management. As a result, some plantations are being "creamed" and some species, as well as plantations away from the roads. are underutilized.

In general, the supplies from the FD plantations have been unreliable, fluctuating and often of poor quality. This state of affairs has not been good for the acceptance of plantation wood in the market and for this reason also many plantations have been left overstocked and underutilized.

A recent indicative inventory has revealed that the natural forest areas assigned for production cannot be exploited in the near future and that they may have to be rested for at least 20-30 years, since the available growing stock is very poor. The present rate of plantation establishment and management by the state is therefore much less than what is required.

\section{Future trends}

As projected in the FSMP, on current trends the wood supply from the existing forest plantations will start decreasing after two decades. (See Figure 1 reproduced from FSMP). This supply estimate takes into account the prevailing negative trends and shortcomings, as well as the current rate of planting. 
Studies on Sri Lanka's wood supply have revealed that even at present the greater part of it comes from non-forest sources. A survey made in 1985 to assess the timber available to consumers indicated that $50 \%$ of industrial logs and $80 \%$ of fuelwood came from land outside the state forests, such as homesteads and village gardens. A review of the situation in 1994 showed that the supply of industrial logs from sources outside the state forests had increased from $50 \%$ of the total consumption to $70 \%$. It is projected that this trend will continue for the next 25 years. The demand for logs will increase from about 1.3 million $\mathrm{m}^{3}$ in 1992 to almost 1.9 million $\mathrm{m}^{3}$ in 2020 . At present the share of total log consumption supplied from forest plantations is only about $4 \%$.

Under these circumstances, ways and means have to be found for increasing the part played by the rural people in tree growing, in order to increase the productivity of the non-forest wood sources. Promoting social forestry is seen as a positive step that could be taken in this direction. It should include tree growing on homesteads, and other agro-forestry systems involving local people, rural communities, NGOs and other nonstate sector bodies.

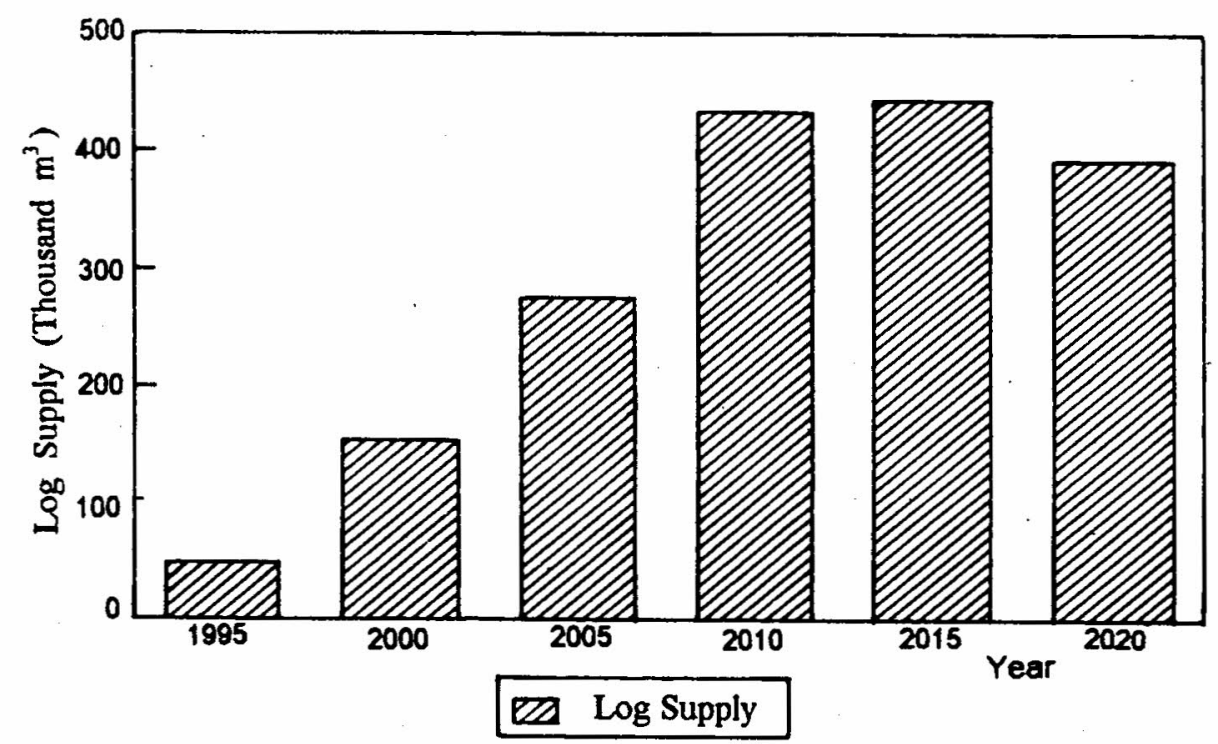

Figure 1 - Wood supply from the existing forest plantations, on current trends (FSMP)

\section{The National Forestry Policy}

The National Forestry Policy (NFP) of 1995 outlines the main provisions targeted towards the development and promotion of social forestry, especially in the following statements: 
3.1 - Tree growing on homesteads and other agroforestry will be promoted as a main strategy to supply wood and other forest products for meeting household and market needs.

3.2 - The establishment, management and harvesting of industrial forest plantations by local people, communities, industries and others in the private sector will be promoted.

3.3 - The state will promote tree growing by local people, rural communities, NGOs and other non-state sector bodies, for the protection of environmentally sensitive areas.

These policy statements are consistent with the government's economic policy. Enlisting the participation of people for forest management has been a key area of action for the last two decades. The FD has been playing the central role in the implementation of various forest policies and programmes during this period. An cxamination of the implementation programmes indicates that that the forestry sector is now poised to make participatory management of the forest resources the main principle governing its activities. The policy of the forestry sub-sector of the Ministry of Agriculture. Lands and Forestry (MALF) has been developed in this new direction. The policy states that "In all areas of forestry development, securing the participation of communities will be assured in the best possible manner".

In line with the government's economic policy, ways must be developed and promoted for involving local farmers, the estate sector, communities. and other local privatesector groups in forest plantation establishment and management of the forest resources - for example through leasehold forestry. Under the right conditions, individual farmers and organized groups will have the resources to manage small blocks.

\section{Forestry Sector Master Plan}

The FSMP contains specific strategies for the development and promotion of social forestry. Along with the sub-programmes for multiple-use forests and forest plantations, the one for home gardens and other non-forest tree resources forms part of the overall FSMP programme for forests and tree resources.

The long term goals of this programme are:

- Class IV forests (forest plantations and agroforestry) will be accepted as part of a permanent national forest estate.

- Home gardens and other agroforestry systems will be allowed on leased state land that has become deforested. A system of incentives will encourage the maintenance of home gardens and conversely, discourage the conversion of home gardens to other land uses. However, home gardens are not to be promoted as part of a settlement policy which might result in clearing natural forests. 
- The home gardens will be productive and managed sustainably by the rural people, yielding a sustained flow of the products and services that they and the rest of society need.

- Trees will be optimally incorporated in various farming systems. More trees will be planted along roadsides and in settlement areas.

- The development and management of home gardens and the incorporation of more trees in other land uses will contribute sustainably to raising the incomes and living standards of the people, as well as to the development of the forest-based industries and the economy in general.

- State agencies, local government units and non-governmental organizations will work with the nural people, promoting the growing of trees and the productivity of home gardens.

- Wood production aspects will be integrated in the research and extension activities of the agencies dealing with rubber and coconut.

\section{Programme components}

The long-term goals are to be attained by means of the following components:

- Creation of a permanent forest estate, which may incorporate some agroforestry systems as part of Class IV forests, along with forest plantations. The MALF will initiate the legal process of defining and creating the forest estate, with the FD providing the necessary support.

- Establishment of criteria for leasing state land for home gardens and other agroforestry systems. Under the guidance of the MALF and the Land Commissioner's Department, the FD will lead a multi-sectoral committee to establish a set of criteria for leasing state lands. NGOs will be represented in the committee to speak for the interests of the rural people.

- Mapping of state land suitable for agroforestry development. The Class IV forests will be mapped, starting with sites which are likely to be in demand for use as agroforestry systems. Mapping will proceed steadily, and will be completed in 10-15 years.

- Opening suitable state land for leasing as agroforestry systems: Guidelines will be produced for leasing state land for forest-based land uses. The guidelines will include the need to provide information to prospective lessees about available state land, as well as how suitable lessees should be selected.

- Development and maintenance of agroforestry systems. The development and maintenance of agroforestry systems in productive condition, and the incorporation of trees in different land uses, are the responsibility of the farmers. However, as the state agencies responsible for forest land, the FD and Department of Agriculture will provide continuous supervision for 
agro-forestry development on leased state lands, to ensure that they are not used for other purposes.

- Improved coordination and provision of institutional support for home gardens and other tree growing on non-forest land. Various institutional support will be provided as required, including credit, technical assistance and research. The line agencies dealing with agricultural crops such as rubber and coconuts will be made aware of the importance of these crops from the viewpoint of wood production. Research will be carried out on integrating rubber and coconut production with wood production. Wood production aspects will be integrated in extension activities.

\section{Policy and legal framework}

Lcasing of state land for forestry purposes is already allowed under the present policy. For example, under the Participatory Forestry Project (PFP) farmers can obtain a 25year lease to develop woodlots. In April 1996, the MALF initiated a ncw scheme for leasing 100,000 acres of degraded land to people for reforestation. The scheme is being implemented by the FD. The practice of leasing should be intensified by reinforcing its policy and legal bases and accelerating its application. The first step is to include the encouragement of leasing in the forest policy and to provide a legal basis for the policy. The National Forestry Policy of 1995 already includes provisions for pursuing such objectives as:

- Increasing tree cover to meet the needs of present and future generations for forest products and services.

- Enhancing the contribution of forestry to the welfare of the rural population, and strengthening of the national economy, with emphasis on equity.

- Promoting tree growing on homesteads and in other agroforestry systems as a main strategy to supply wood and other forest products for meeting household and market needs

- Facilitating the harvesting and transport of forest products grown on private land.

- Providing full support by the state to the various resource managers, reorientation of the state agencies, and strengthening them to accomplish their roles.

\section{Proposed strategies}

Key actions that will be undertaken for the attainment of these long-term goals aim, in the short term, at strengthening the capability and coordinating mechanisms of the FD and other supporting insti-tutions, and putting them to work with the rural people. In 
the medium term they aim at continuing and accelerating these activities, and finally attaining the long-term objectives and maintaining the gains thus achieved.

Among the short-term strategies are the passing of forestry legislation, reviewing and re-orientating institutional roles and functions, formulating regulations relating to the establishment of a permanent forest estate, the categorizing the forests (including agroforestry systems) and identifying state land for leasing. mapping of state land to be leased for agroforestry development, involving NGOs in assisting the FD in its extcnsion activities, initiating and accelerating the leasing of state land for agroforestry development, and promoting tree growing in the different land uses, monitoring the leases and fine-tuning the systems and procedures. establishing a monitoring system for tree resources outside forests, and conducting research on genetic improvement of rubber trees and coconuts to improve wood yields and quality.

The medium-term strategies include the expansion of the programme to other areas all over the country.

It is also important to monitor developments in the home gardens sector. There is a need for an inter-agency effort in monitoring the planting, maintenance and utilization of trees grown outside the forests. The MALF is the most appropriate institution to lead this activity. A vital aspect of monitoring is a continuing evaluation of the condition of the trees, their production potential and actual utilization and their effectiveness in ameliorating environmental conditions. The ministry has already launched a very effective progranme designated as "AMA" under which it is expected that all development activities will be undertaken at the Agrarian Centre (Givijana Kendraya) level. involving the integrated participation of the FD and other relevant agencies, the newly recruited motivators (Govi Sevena Niyamakas) and the farmer representatives The ultimate aim is to hand over the forests to people-based organizations for management.

The forestry sector has had various programmes and projects aimed at the achievement of participatory management. At an earlier stage the key one was the Community Forestry Project. funded by the Asian Development Bank (ADB) and implemented by the FD in the 1980s. Based on the lessons learned from this project and in keeping with the government's policy, the Participatory Forestry Project (PFP), covering 18 districts, was launched with ADB assistance in three successive phases, begun in 1993, 1994 and 1995. The PFP supports the institution of a social forestry programme at the FD which involves the local community in developing private woodlots and forestry farms, and the strengthening of extension activities to promote non-forest tree planting. Among the incentives provided to farmers under the PFP are a renewable 25-year leasehold; freedom to choose the tree species; and food aid for labour inputs in the establishment of farm woodlots, protective woodlots and nurseries. A total area of 9031 ha has been put into use under this project. This figure includes 6204 ha under home gardens, 1595 ha under agroforestry systems, 732 ha under protective woodlots, and 500 ha under other types of tree planting. 


\section{Buffer zone tree planting}

The second most important component of social forestry is buffer-zone tree planting. The need for buffer zones has been recognized as a priority requirement in the wet-zone conservation forest areas and to a lesser extent also in the dry zone. The FSMP envisages a protected area system (PAS) covering all three ecological zones. To ensure long-term protection of this PAS it is expected that effective buffer zones will be developed island-wide. with enhanced tree cover and agricultural crops. When the management plans for the thirteen named Conservation Forests are put into effect, tree cover will be increased in the buffer zone, while the earning potential of resident villagers is improved by their engagement in other agricultural pursuits.

Various agroforestry systems have also been developed to optimize the combination of trees and agricultural crops. The point to be emphasized here is that in employing such systems the farm land can still acconmodate more trees without agricultural production being adversely affected.

\section{Conclusion}

In the light of the above findings it can be concluded that if properly implemented with genuine commitment. social forestry can be seen as the main alternative strategy for forest plantation development, which will not only increase the tree cover of this country but will also heip in meeting the basic timber and fuelwood needs of the people.

\section{References}

FSMP (1995). Sri Lanka Forestry Sector Master Plan. Ministry of Agriculture. Lands and Forestry. 